\title{
PRÁTICAS PEDAGÓGICAS AKWẼ E PRÁTICAS PEDAGÓGICAS DAS ESCOLAS AKWẼ
}

\author{
XERENTE ${ }^{1}$, Adão Wdêrêhu \\ Universidade Federal de Goiás
}

\section{RESUMO}

Neste artigo, discuto duas pedagogias distintas e que fazem parte da vida da criança Akwẽ.

Palavras-chave: Educação Akwẽ. Práticas pedagógicas. Criança Akwẽ.

\section{ABSTRACT}

In this article, I discuss two distinct pedagogies that are part of the Akwẽ child's life.

Key words: Akwẽ Education. Pedagogical Practices. Akwẽ Child.

Este artigo visa descrever as duas pedagogias distintas e que fazem parte da vida da criança Akwẽ. O modelo de educação escolar vigente tem contribuído significativamente na deficiência do ensinoaprendizagem na fase inicial da vida escolar, tempo em que a criança está no auge das descobertas e aprendizagens.

$\mathrm{Na}$ primeira pedagogia em que a criança está aprendendo, não há necessidade de ir todos os dias para a escola e ter que ficar presa na sala de aula por algumas horas. São aprendizados rápidos e de forma espontânea, porque ela está aprendendo literalmente livre e a criança vai selecionando o seu próprio conhecimento.

A segunda pedagogia é que, nesse mesmo período, a criança passa a frequentar a escola e começa a conhecer o outro método de aprendizagem, que é inverso do que está aprendendo na vida, que exige ficar quieta, não pode falar a vontade, tem horário certo para entrar e sair e suas vontades são limitadas. Ainda, para completar, muitos professores Akwẽ não se atentam em iniciar a vida escolar de seus alunos, trabalhando com os conhecimentos que eles trazem de casa e, aos poucos, estendendo para fora, ou seja, estendendo para o espaço escolar. A criança começa a se desmotivar por falta de liberdade.

1 Rede UFG/UFT/UFMA. Professor de Educação Básica. 
Quis alcançar, com esse trabalho, uma metodologia em que a criança Akwẽ não tenha muitas dificuldades em aprender a ler e a escrever. Para isso, usei os métodos que identificaram as práticas pedagógicas onde elas aprenderam a ler e a escrever sem maiores dificuldades. Para isso, foram realizadas visitas às roças de toco dos pais de alunos; foi realizado o banho coletivo no rio; fomos para o cerrado coletar pequi, cajuí, puçá, mangaba etc.

Listei alguns conhecimentos adquiridos pelas crianças que foram naturalmente perguntados por elas durante as realizações dos trabalhos. A partir disso, elaborei os planos de aulas onde os nomes de pássaros, plantas, peixes, frutos, entre os animais e vegetais serviram de conteúdos, e que já fizeram parte do conhecimento prévio das crianças antes de entrarem na sala de aula, os quais não tiveram dificuldades em aprender a identificar as letras, associando com o que viram e aprenderam durante as visitas, banhos e coletas de frutos.

Das trinta e uma escolas indígenas Akwẽ, três têm a Educação Infantil funcionando. As outras só atendem a partir do $1^{\circ}$ ano e só matriculam crianças a partir dos seis anos de idade. Pode ser um dos fatores contribuintes para a deficiência de ensino-aprendizagem dos nossos alunos. Mas isso não é o principal fator, porque se nota que, em muitos casos, as crianças começaram a estudar com sete, outras com oito anos de idade e tiveram sucesso na sua aprendizagem.

A grande maioria dos casos são resultados das práticas pedagógicas em que as escolas trabalharam ou estão trabalhando e que não atendem a realidade das crianças e isso tem resultado em que elas aprendem somente a copiar palavras e textos e muito pouco aprendem a ler. Exatamente porque a escola onde a criança começou a estudar não teve o cuidado de iniciar os trabalhos aproveitando os conhecimentos que a criança trouxe de casa.

A minha observação começou com o acompanhamento nos anos de 2000 a 2003 quando trabalhei com as turmas das séries iniciais e depois com acompanhamento do meu filho Prewẽ, que foi matriculado com seis anos de idade. Esse ano, com 11 anos de idade, vai cursar $6^{\circ}$ ano, porém, só agora está começando a ler, mas ele aprendeu a copiar cedo. E, assim, são muitos outros alunos de outras escolas.

Um dos outros fatores bastante comuns nas escolas Akwẽ está na falta de materiais didáticos específicos para os nossos alunos, porque os que a SEDUC manda para nós são materiais didáticos com 
realidades dos não indígenas e os trabalhos pedagógicos acabam caindo na rotina, porque os nossos professores se prendem aos livros por ser mais fácil de planejar aulas com o que tem nos livros e escrever palavras e textos na lousa para os alunos copiarem. É aí que está um grande obstáculo a ser rompido. Até há poucos anos, a falta de formação dos nossos professores também era um fator preocupante, porque não existe educação escolar de qualidade sem a formação adequada.

Durante décadas, as práticas pedagógicas das nossas escolas foram de tradução da língua portuguesa para a língua materna e viceversa. Era o máximo que podiam fazer para trabalharem a Educação Bilíngue, Diferenciada, Específica e Comunitária. Vale destacarmos as observações feitas pelos autores Nascimento e Urquiza (2012). Em seu artigo questionam que depois de duas décadas da efetivação da educação escolar indígena, "em quais elementos houve avanço; onde a experiência de tradução e diálogo intercultural obteve mais êxito; porque a escola é ainda ocidentalizante?".

Esses mesmos autores tiveram a experiência de acompanhar a educação escolar indígena em Mato Grosso do Sul, dos Guarani e Kaiowá no sul do estado. Os autores concordam que essas experiências têm trazido ao contexto escolar, saberes, crenças e valores indígenas que, durante séculos, foram silenciados pelo modelo de ensino ocidental, e que agora estão sendo ressignificados através do diálogo intercultural.

Essa observação tem muito a ver com a Educação Escolar Akwẽ que, atualmente, estamos conquistando a sonhada formação de professores no Curso Superior de Licenciatura em Educação Intercultural da Universidade Federal de Goiás. Em 10 anos de implantação do curso já percebemos uma diferença bastante significativa, tanto nas práticas pedagógicas quanto na produção de materiais específicos para as escolas Akwẽ, o que está começando a se refletir no ensino-aprendizagem dos nossos alunos.

Uma das prioridades mais urgentes consideradas por nós, professores Akwẽ é a elaboração da Proposta de Políticas Pedagógicas para as Escolas Akwẽ, na qual estamos em fase de construção, iniciada pelos/a professores/a do Curso de Especialização em Educação Intercultural e Transdisciplinar: Gestão Pedagógica oferecido pelo Núcleo Takinahakỹ de Formação Superior Indígena da Universidade Federal de Goiás (UFG): Sinval Waĩkazate, Silvino Sirnãwẽ, Carmelita Krtidi e Gilberto Srõsdazê. 
Sabemos que para essa proposta ser reconhecida pela SEDUC - TO, é necessário que lutemos em busca de reconhecimento, porque o Estado tem um tratamento de não dar muita importância às propostas, por considerar que a padronização educacional é mais fácil de trabalhar e, com isso, muitos de nós não temos a segurança e sempre acabamos aceitando essas propostas da SEDUC.

\section{REFERÊNCIA BIBLIOGRÁFICA}

NASCIMENTO, Adir Casaro; URQUIZA, Antonio Hilário Aguilera. Práticas de ensino no contexto das escolas indígenas. XVI ENDIPE - Encontro Nacional de Didática e Práticas de Ensino, UNICAMP. Campinas: Junqueira \& Marin Editores. Livro 1 - p.001094, 2012. 